University of California, Hastings College of the Law UC Hastings Scholarship Repository

Faculty Scholarship

1979

\title{
The Denial of Eleventh Amendment Immunity to Political Subdivisions of the States: An Unjustified Strain on Federalism
}

Margreth Barrett

UC Hastings College of the Law, barrettm@uchastings.edu

Follow this and additional works at: http://repository.uchastings.edu/faculty_scholarship

\section{Recommended Citation}

Margreth Barrett, The Denial of Eleventh Amendment Immunity to Political Subdivisions of the States: An Unjustified Strain on Federalism, 1979 Duke L.J. 1042 (1979).

Available at: http://repository.uchastings.edu/faculty_scholarship/855

This Article is brought to you for free and open access by UC Hastings Scholarship Repository. It has been accepted for inclusion in Faculty Scholarship by an authorized administrator of UC Hastings Scholarship Repository. For more information, please contact marcusc@uchastings.edu. 


\section{Faculty Publications \\ UC Hastings College of the Law Library}

Author: Margreth Barrett

Source: Duke Law Journal

Citation: 1979 Duke L.J. 1042 (1979).

Title: $\quad$ The Denial of Eleventh Amendment Immunity to Political Subdivisions of the States: An Unjustified Strain on Federalism

Originally published in DUKE LAW JOURNAL. This article is reprinted with permission from DUKE LAW JOURNAL and Duke University School of Law. 


\section{THE DENIAL OF ELEVENTH AMENDMENT IMMUNITY TO POLITICAL SUBDIVISIONS OF THE STATES: AN UNJUSTIFIED STRAIN ON FEDERALISM*}

\section{Political Subdivisions of the State as Independent ENTITIES UNDER THE ELEVENTH AMENDMENT: AN EXCEPTION TO THE CONSTITUTIONAL RULE}

Throughout the history of the United States the Supreme Court has maintained that cities, counties, and other such political subdivisions are constitutionally indistinguishable from the state that created them. A major exception to this rule arises under the eleventh amendment, however, for the courts have consistently held that while states themselves are immune from suit in federal court, their subdivisions may not share in this immunity. This Comment will examine the impact of this exception on the balance of powers between union and state and seek an explanation that justifies the strain the exception places on the principles of federalism.

\section{A. The General Rule: Political Subdivisions are Indistinguishable from the State that Creates Them.}

Very early in the nation's history the Supreme Court firmly expressed the view that cities, counties, and other political subdivisions were indistinguishable parts of the states that created them. The cases dealing with the question described state political subdivisions as "convenient agencies"1 for exercising government powers, "mere creatures of the legislative will," "parts of the machinery,"3 "imstrumentalities,"

* The author wishes to thank Professor William W. Van Alstyne for his invaluable advice on the issues raised in this Cominent.

THE FOLLOWING CITATIONS WILL BE USED IN THIS COMMENT:

C. Jacobs, The Eleventh Amendment and Sovereign Immunity (1972) [hereinafter cited as C. JACOBS];

Baker, Federalism and the Eleventh Amendment, 48 U. CoLO. L. Rev. 139 (1977) [hereinafter cited as Baker].

1. Hunter v. City of Pittsburgh, 207 U.S. 161, 178 (1907); see City of Trenton v. New Jersey, 262 U.S. 182, 185-86 (1923).

2. Commissioners of Laramie County v. Commissioners of Albany County, 92 U.S. 307, 312 (1875); see City of Trenton v. New Jersey, 262 U.S. at 187. 
"departments,"5 and "auxiliaries"6 of the state. They stressed the states" unbridled power to create, control, and demolish their subdivisions ${ }^{7}$ and to control the governmental property over which the subdivisions exercised domain. ${ }^{8}$ The Court's discussion of the status of a city in Worcester v. Worcester Consolidated Street Railway ${ }^{9}$ states this principle:

[A] municipal corporation is not only a part of the State but is a portion of its governmental power. "lt is one of its creatures, made for a specific purpose, to exercise within a limited sphere the powers of the State. The State may withdraw these local powers of government at its pleasure, and may, through its legislature or other appointed channels, govern the local territory as it governs the State at large. It may enlarge or contract its powers or destroy its existence." 10

The many cases Worcester represents reiterate two themes: first, the acts of political subdivisions are the acts of the state; second, in acting through its political subdivisions, a state merely exercises indi-

3. City of Worcester v. Worcester Consol. St. Ry., 196 U.S. 539, 549 (1905); Commissioners of Laramie County v. Commissioners of Albany County, 92 U.S. at 310.

4. Louisiana v. Folsum, 109 U.S. 285, 287 (1883); see Railroad Co. v. County of Otoe, 83 U.S. (16 Wall.) 667, 676 (1872); Trustees of Dartmouth College v. Woodward, 17 U.S. (4 Wheat.) 517,638 (1819).

5. City of Trenton v. New Jersey, 262 U.S. at 187; Barnes v. District of Columbia, 91 U.S. 540,544 (1875).

6. Commissioners of Laramie Couuty v. Commissioners of Albany County, 92 U.S. at 311.

7. In Hunter v. City of Pittsburgh, 207 U.S. 161 (1907), the Court stated:

The number, nature, and duration of the powers conferred upon these [political subdivisions] and the territory over which they shall be exercised rests in the absolute discretion of the State. . . The State, therefore, at its pleasure may modify or withdraw all sucls powers, may take without compensation sucli property, hold it itself, or vest it im other agencies, expand or contract the territorial area, unite the whole or a part of it with another municipality, repeal the charter and destroy the corporation. All this may be done, conditionally or unconditionally, with or without the consent of the citizens, or even against their protest. In all these respects the State is supreme, and its legislative body, conforming its action to the state constitution, may do as it will, unrestrained by any provision of the Constitution of the United States.

Id. at 178-79 (1907); see City of Trenton v. New Jersey, 262 U.S. at 187; Missouri v. Lewis, 101 U.S. 22, 30 (1879); Mount Pleasant v. Beckwith, 100 U.S. 514 passim (1879); Commissioners of Laramie County v. Commissioners of Albany County, 92 U.S. at 313.

8. See Guthrie Nat'l Bank v. Guthrie, 173 U.S. 528,530 (1899) (the state may direct that a nunicipal corporation collect a particular tax and appropriate the proceeds to some special purpose, or it may direct that the corporation assume and pay a particular claim); Board of Comm'rs v. Lucas, 93 U.S. 108, 114 (1876) (since municipal property is derived from the state or obtamed by means that only the state can authorize, it is conpletely subject to legislative control and can be applied to whatever purpose the state deens appropriate); Commissioners of Laramie County v. Commissioners of Albany County, 92 U.S. at 313 (state may order new roads to be built at the expeuse of the county).

9. 196 U.S. 539 (1904).

10. Id. at 549 (quoting United States v. Railroad Co., 84 U.S. (17 Wall.) 322, 329 (1872)). 
rectly the same power that it might exercise directly. ${ }^{11}$

Modern constitutional law contmues to recognize that the delegation of power by a state does not create a distmct sovereign entity. ${ }^{12}$ This is clearly illustrated by the fact that clauses of the Constitution that linit the states, such as the double jeopardy clause ${ }^{13}$ the equal protection clause, ${ }^{14}$ the due process clause, ${ }^{15}$ and the contracts clause, ${ }^{16}$ also limit their political subdivisions.

In Waller v. Florida, ${ }^{17}$ for example, the Supreme Court held that a defendant convicted in inunicipal court for violation of a city ordinance could not be convicted on a state charge for the same act, as the second trial would constitute double jeopardy under the fifth and fourteenth amendments. In answer to the State's argument that cities are autonomous entities set apart from the state much as the states are set apart froin the federal government, the Court rephed: "Political subdivisions of States-counties, cities, or whatever-never were and never have been considered as sovereign entities. Rather, they have been traditionally regarded as subordinate governmental instrumentalities created by the State to assist in the carrying out of state governmental functions." 18

In Waller the Court recognized the existence of only two sovereign entities withm the United States-the federal and the state governments. Moreover, the opmion made it clear that although the state may delegate its sovereignty, it cannot multiply it.

Reapportionment cases, such as Avery v. Midland County, ${ }^{19}$ reinforce the view expressed by the Court in Waller. In Avery, the Court found that although the Texas state legislature was itself properly apportioned, the act of a county commission in improperly apportioning itself constituted state action subject to the restraints of the equal protection clause. In support of its decision the Court explained that "[t]he Equal Protection Clause reaches the exercise of state power however

11. City of Trenton v. New Jersey, 262 U.S. at 186; Guthrie Nat'l Bank v. Guthrie, 173 U.S. at 529-30; Railroad Co. v. County of Otoe, 83 U.S. (16 Wall.) 667, 676 (1872).

12. See, e.g., Holt Civic Club v. City of Tuscaloosa, 439 U.S. 60, 71 (1978).

13. U.S. CoNST. amend. V: "[N]or shall any person be subject for the same offence to be twice put in jeopardy of life or limb...."

14. U.S. CoNST. amend. XIV, § I: "No State shall . . . deny to any person . . . the equal protection of the laws."

15. U.S. CoNST. amend. XIV, § l: "[N]or shall any State deprive any person of life, liberty, or property, without due process of law ...."

16. U.S. Const, art. I, $\S 10$, cl. 1: "No state shall . . pass any . . . Law impairing the Obligation of Contracts ....."

17. 397 U.S. 387 (1970).

18. Id. at 392 (quoting Reynolds v. Sims, 377 U.S. 533, 575 (1964)).

19. 390 U.S. 474 (1968). 
manifested, whether exercised directly or through subdivisions of the State. . . . The actions of the local government are the actions of the State." 20

A further illustration is the fact that the Court has generally held that local ordinances are equivalent to state laws. Thus the actions of local officials taken under color of city or county ordinances are actions of the state, limited by the contracts clause, ${ }^{21}$ the equal protection clause, $^{22}$ and the due process clause. ${ }^{23}$ Further, political subdivisions are subject to the limitations imposed on states by the fourteenth amendment's incorporation of the provisions of the Bill of Rights. ${ }^{24}$

\section{B. The Rationale for the General Rule: The Power to Delegate as an Important Element of the State's Sovereignty.}

The Supreme Court has characterized the power to delegate authority as an essential component of each state's sovereignty, for the tenth amendment ${ }^{25}$ protects the states' right to define and organize their own governmental functions im a manner that suits their particular needs and convenience. "[I]t would seriously interfere with the power of a State . . . to deny to it this right [to delegate]."26

20. Id. at 479-80; see Hadley v. Junior College Dist., 397 U.S. 50, 56 (1970).

21. U.S. Const. art. I, $\$ 10$, cl. 1. See, e.g., Mercantile Trust \& Deposit Co. v. City of Columbus, 203 U.S. 311,320 (1906) ("That the ordinance of the common counsel of a municipal corporation may constitute a law within the meaning of this constitutional clause is too well settled to admit of doubt").

22. See, e.g., Hunter v. Erickson, 393 U.S. 385, 392 (1969) (acknowledging the state's interest in delegating authority as well as the people's interest in retaining certain powers on a local level, but finding that the state is nonetheless responsible for local governmental activities that violate the equal protection clause); Burton v. Wilmington Parking Auth., 365 U.S. 715 (1961) (state action found when the parking authority, created by the city, leased space in a building it owned to a private restaurant that discriminated against blacks); Cooper v. Aaron, 358 U.S. 1, 15-16 (1958) (actions of local school officials in school segregation case found to be actions of the state in violation of the equal protection clause); Peunsylvania v. Board of Directors of City Trusts, 353 U.S. 230 (1957) (state action found in discriminatory actions of city board of directors, despite state disapproval of the activities, as indicated by the fact that the state joined in the suit against the board); Lovell v. City of Griffin, 303 U.S. 444, 450 (1938) (any municipal ordinance adopted under state authority constitutes state action for purposes of the fourteenth amendment).

23. See, e.g., Thompson v. City of Louisville, 362 U.S. 199 (1960) (local charges based on city loitering and disorderly conduct ordinances so devoid of evidentiary support as to violate the due process clause).

24. See, e.g., See v. Seattle, 387 U.S. 541 (1967) (city ordinance violated the fourth amendment as applied to the states through the fourteenth amendenent); Terminiello v. Chicago, 337 U.S. 1 (1949) (city ordinance violated first amendment as apphied to the states through the fourteenth amendment).

25. U.S. Const. amend. X: "The powers not delegated to the Umited States by the Constitution, nor prohibited by it to the States, are reserved to the States respectively, or to the people."

26. Missouri v. Lewis, 101 U.S. 22, 31 (1879); see Ohio Life Ins. \& Trust Co. v. Debolt, 57 U.S. (16 How.) 416, 428 (1853) (Taney, C.J., plurality opinion): 
In San Antonio Independent School District v. Rodriguez, ${ }^{27}$ an equal protection case, the Court emphasized the importance of the states' self-structuring and delegating power and their need to exercise this power free of federal interference. In Rodriguez, the Supreme Court refused to overturn the Texas system of allocating state support to schools in proportion to the amount of local taxes each district could raise, though the system had a differential impact on poor and wealthy districts. Relying on the principles of federalism, the Court cliaracterized the suit as

nothing less than a direct attack on the way in which Texas has chosen to raise and disburse state and local tax revenues. We are asked to condemn the State's judgment in conferring on pohitical subdivisions the power to tax local property to supply revenues for local interests. In doing so, appellees would have the Court intrude in an area in which it has traditionally deferred to state legislatures. ${ }^{28}$

Reiterating the importance of traditional state structural autonony, the Court carried its Rodriguez rationale even further in National League of Cities v. Usery. ${ }^{29}$ In that case the Court invoked the tenth amendment to invalidate the 1974 amendments to the Fair Labor Standards Act, ${ }^{30}$ which extended minimum wage and maximum lour provisions to employees of states and their political subdivisions. The Court reasoned that the amendments would impose substantial costs upon states and their political subdivisions, and that this imposition threatened to disrupt the states' chosen methods of structuring and delivering traditional governmental services. ${ }^{31}$ This federal interference with the states' integral functions was impermissible because it might lead to the destruction of the "the States' 'separate and independent existence." "32

These cases, like those discussed in the preceding section, suggest that a state's governmental power is ultimately unitary. They further suggest that the state's decision to create pohitical subdivisions and

[W] ith the exception of the powers surrendered by the Constitution of the United States, the people of the several States are absolutely and unconditionally sovereign within their respective territories. . . The principle that they are the best judges of what is for their own interest, is the foundation of our political institutions. Id. at 428.

27. 411 U.S. 1 (1972).

28. Id. at 40 (footnotes ounitted).

29. 426 U.S. 833 (1976).

30. Pub. L. No. $93-259,88$ Stat. 55.

31. 426 U.S. at 847-48. According to the Court, the "pohitical subdivisions" that Congress desired to subject to its requirements derive their authority and power from the states that created them. Interference with the integral governmental services provided by these "subordinate arms of state government," therefore, is beyond congressional power, "just as if such services were provided by the state itself." Id. at 855 n.20.

32. Id. at 851 . 
delegate its power to them is itself a vital part of the state's sovereignty. Federal interference with a subdivision performing a delegated act is therefore equivalent to federal interference with the state itself. In effect, as a general rule, a state neither gams nor loses by its decision to delegate or not to delegate. It cannot, by delegating authority, circumvent the Constitution's controls on states. ${ }^{33}$ Likewise, a state normally loses none of its powers or discretion by delegating, since it retains complete control over its subdivisions, free of federal interference. ${ }^{34}$

\section{The Exception: Political Subdivisions as Independent Entities for Eleventh Amendment Purposes.}

Despite its consistent holdings under other sections of the Constitution that the state and its political subdivisions form a single unit, the Supreme Court has long held that under the eleventh amendment, ${ }^{35}$ the states and their pohtical subdivisions are separate entities. ${ }^{36}$ Thus, while suits against a state nay not be brought in federal court without the state's consent, no consent is necessary for suits against counties, municipalities, and other such "independent" ${ }^{37}$ political subdivisions.

The notion that political subdivisions are independent entities is

33. See notes 11-24 supra and accompanying text.

34. See notes 25-26 \& 31 supra and text accompanying notes 25-32 supra. As the Court stated in Commissioners of Laramie County v. Commissioners of Albany County, 92 U.S. 307 (1875): "It is settled law, that the legislature, in granting [governmental power to a municipality or county], does not divest itself of any power over the inhabitants of the district which it possessed before the charter was granted." Id. at 308 . These subdivisions have no inherent right of selfgovernment that places them beyond the legislative control of the state. City of Trenton v. New Jersey, 262 U.S. 182, 186 (1923). The arrangements made between the state and its political subdivisions are not considered contracts and are, accordingly, not subject to the contracts clause of the Constitution, Newton v. Commissioners, 100 U.S. 548, 558-59 (1879), nor does the contracts clause or the due process clause mhibit the state from withdrawing or otherwise disposing of property held by the subdivision for governmental purposes, City of Trenton v. New Jersey, 262 U.S. at 188. See Hunter v. Pittsburgh, 207 U.S. 161, 178-81 (1907).

35. U.S. CoNST. amend. XI: "The Judicial power of the United States shall not be construed to extend to any suit in law or equity, commenced or prosecuted agamst one of the United States by Citizens or Subjects of any Foreign State."

36. See, e.g., Lake Country Estates, Inc. v. Tahoe Regional Planning Agency, 440 U.S. 391 (1979); Edelman v. Jordan, 415 U.S. 651 (1974); Lincoln County v. Luning, 133 U.S. 529 (1890). There are two other notable exceptions to the rule: subdivisions are not part of the state for purposes of 28 U.S.C. $\$ 1251$ (a) (1976), which grants federal jurisdiction in "[a]ll controversies between two or more states," Edelman v. Jordan, 415 U.S. at 684 (Douglas, J., dissenting); see Illinois v. Milwaukee, 406 U.S. 91, 98 (1971), nor are they in all cases a part of the state for purposes of the state action exemption from the antitrust laws, Parker v. Brown, 317 U.S. 341 (1943); City of Lafayette v. Louisiana Power \& Light Co., 435 U.S. 389, 414-15 (1978).

37. Cities and counties are always considered independent from the state for eleventh amendment purposes. A large body of case law exists concerning which pohtical subdivisions other than cities and counties are independent-and therefore unprotected-and which subdivisions are simply alter egos of the state. See, e.g., S.J. Groves \& Sons v. New Jersey Turnpike Auth. 268 F. Supp. 568, 574 (D.N.J. 1967). See text accompanying notes 50-54 infra. 
puzzling for reasons other than the inconsistency with the holdings under other portions of the Constitution. This notion is also in apparent conflict with constitutional doctrines expressed in the tenth and eleventh ainendinents. The Court has recognized that a purpose of the eleventh amendment is to protect the internal administration of the sovereign state froin federal encroachment. ${ }^{38}$ Nonetheless, in differentiating between states and political subdivisions in eleventh anendinent cases, the Court ignores this purpose. If a state decides to keep a particular fiscal or regulatory authority within the governmental framework of "the state" itself, it may use that authority without fear of suit in federal court. But if it chooses to delegate the authority to an incorporated political subdivision, both the subdivision and, practically speaking, the state, will be subject to unconsented-to suits for inoney damages in federal courts. Thus, the state's protection against suits in federal court depends almost entirely on whether or not it decides to delegate. ${ }^{39}$ Differentiation of states froin their political subdivisions under the eleventli ainendinent appears directly to undercut the Court's policy of honoring the sțate's prerogative to structure and deliver traditionally local governmental services in the manner it clooses. ${ }^{40}$

In effect, "state," as a word or concept, has been given different meanings under separate parts of the Constitution. While different meanings should not alone be rennarkable, ${ }^{41}$ it is appropriate to seek a

38. See notes 110-16 infra and accompanying text.

39. "Immunity under the Eleventh Amendment is an attribute of the State only in its corporate sovereign capacity; if our complex society necessitates delegation of certam tasks to independent agents for the State, the rationale of the amendment does not dictate its extension to them as well." S.J. Groves \& Sons v. New Jersey Turnpike Auth., 268 F. Supp. 568, 579 (D.N.J. 1967). See Note, State Governmental Corporation Immunity from Federal Jurisdiction Under the Eleventh Amendment, 72 Dick. L. Rev. 296, 298-99 (1968).

Likewise, even when "the state" itself undertakes a purely proprietary, as opposed to governmental, function, it inay be immune from suit, see, e.g., Murray v. Wilson Distilling Co., 213 U.S. 151 (1909). Its subdivisions performing strictly governmental functions directed by the state, however, will not be granted immunity. Lake Country Estates, Inc. v. Tahoe Regional Planning Agency, 440 U.S. 391, 401 (I979) ("[T] he Court has consistently refnsed to construe the [Eleventh] Amendinent to afford protection to political subdivisions such as counties and mumicipalities, even though sucl entities exercise a 'slice of state power'").

40. See notes 26 \& 31 supra and text accompanying notes 26-32 supra.

41. For instance, the term "citizen" is held to mclude private corporations for purposes of diversity jurisdiction under article III, Louisville, C. \& C.R.R. v. Letson, 43 U.S. (2 How.) 497, 555 (1844), but not under the privileges and immunities clauses of the fourteenth amendment, Selover, Bates \& Co. v. Walsh, 226 U.S. 112, 126 (1912), or article IV, Liverpool Ins. Co. v. Massachnsetts, 77 U.S. (10 Wall.) 566,573 (1870). Likewise, the term "person" nuay include private corporations for purposes of the due process and equal protection clauses of the fourteenth amendment, Louis K. Liggett Co. v. Lee, 288 U.S. 517, 536 (1933); Pierce v. Society of Sisters, 268 U.S. 510, 535-36 (1925), but not for purposes of the fifth amendment right against self-incrimination, Curcio v. United States, 354 U.S. 118, 122 (1957). 
rational explanation for the variance. If the difference in interpretation serves some purpose, that purpose should then be weighed agamst the infringement on state sovereignty caused by its promotion. ${ }^{42}$

\section{A SEARCH FOR the REASONS BEHIND THE EXCEPTION}

\section{A. Explanation by the Courts.}

1. The Court's Explanation Upon Establishing the Exception. Political subdivisions were sued regularly im federal courts without objection at the time of Chisholm v. Georgia, ${ }^{43}$ the 1793 case in which the Supreme Court took federal jurisdiction over a state in a private suit for damages, thus sparking the controversy leading to passage of the eleventh amendment. ${ }^{44}$ Ratification of the eleventh amendment did not abate these suits against political subdivisions.

The Supreme Court first squarely faced the issue of subdivision immumity in Lincoln County v. Luning, ${ }^{45}$ a century after passage of the eleventh amendment. In Lincoln, the defendant county attempted to claim the sovereign immunity of the state under the eleventh amendment as a bar to jurisdiction. The Court unanimously rejected the contention, stating:

[I]t may be observed that the records of this court for the last thirty years are full of suits against counties, and it would seem as though by general consent the jurisdiction of the Federal courts in such suits had becoine established. But irrespective of this general acquiescence, the jurisdiction of the Circuit courts is beyond question. The Eleventh Amendment limits the jurisdiction only as to suits against a State. It was said by Chief Justice Marshall, in Osborn v. The Bank of the United States, 9 Wheat. 738, 857, that "the Eleventh Amendment, which restrains the jurisdiction granted by the Constitution over suits against States, is of necessity limited to those suits in which the State is a party on the record."

While that statement was held by this court in the case of In re Ayers, 123 U.S. 443, to be too narrow, yet by that decision the jurisdiction was limited only in respect to those cases in which the State is a real, if not a nominal defendant; and while the county is territorially a part of the State, yet politically it is also a corporation created by and with such powers as are given to it by the State. In this respect it is a part of the State only in that remote sense in which any city, town, or other inunicipal corporation may be said to be a part of

42. This Comment does not purport to evaluate the usefulness or philosophical consistency of the eleventh amendment as a whole.

43. 2 U.S. (2 Dall.) 419 (1793).

44. In Chisholm, Chief Justice Jay, in deciding that the states were subject to suit in federal court, noted that a private citizen could sue a municipality and that there was no rational basis for granting the citizens of a state immunity when the citizens of a municipality had none. Id. at 472.

45. 133 U.S. 529 (1890). 
the State. ${ }^{46}$

This discussion, apart from vague references to the fact of incorporation, offers no reasoning in support of the finding that subdivisions are entities apart from the state for purposes of jurisdiction. Instead, past practices alone served as the basis for the Lincoln County result. ${ }^{47}$

Lincoln County is now routinely cited as the authority for denying political subdivisions eleventh amendment protection. Rather than questioning or explaining the basis for the Lincoln County rule, ${ }^{48}$ recent cases focus on whether a particular governmental entity is sufficiently independent of the state (or sufficiently similar to a county or city) to justify the loss of immunity. ${ }^{49}$

Since the courts have failed to offer any explicit explanation for the Lincoln County rule, an explanation must be sought from some other source. One possible source is the eleventh amendment case law developed by courts in deciding whether particular governmental entities are a part of the state or, like cities and counties, independent subdivisions subject to suit in the federal courts. Factors used in making this differentiation may provide a clue to the purpose for which the distinction is made. A second source is the theoretical foundations of the eleventh ainendment and an examination of whether the amendinent's purposes are proinoted by excluding subdivisions froin coverage.

2. Indirect Explanation Through Courts'Application of the Exception. At the time of Lincoln County the structure and services of state government were relatively simple. The complex, highly specialized

46. Id. at 530 .

47. See Camden Interstate Ry. v. Catlettsburg, 129 F. 421,423 (C.C.E.D. Ky. 1904):

[T] $T$ he amendment in question does not deny jurisdiction to the federal courts of the suit, for it denies to them jurisdiction only of suits against "one of the United States," and not against a subdivision thereof. If the federal courts do not, by reason of said amendment, have jurisdiction of suits against municipal corporations, it is hard to understand upon what ground it has been that they have so often taken jurisdiction of suits against them. Id. at 423 .

48. Courts holding that the acts of political subdivisions are "state actions" restricted by the fourteentl amendment but that the subdivisions are not "state defendants" within the meaning of the eleventh amendment often acknowledge the inconsistency in the two definitions of "state." Nevertheless, the courts offer no rationale for the difference. See, e.g., Edelman v. Jordan, 415 U.S. 651, 667 n. 12 (1974); Burt v. Board of Trustees, 521 F.2d 1201, 1205 (4th Cir. 1975); Adams v. Richland School Dist. One, 412 F. Supp. 647,649 (D.S.C. 1976). See also Mathis, The Eleventh Amendment: Adoption and Interpretation, 2 GA. L. REv. 207, 242 (1968).

To add to the general confusion, while the subdivision itself nay be subject to suit in federal court even though it performs state governmental functions, an official of the subdivision who is named as an individual defendant in the same action may claim immunity from suit under the principles governing suits agaimst state officers. See C. JACOBS $188 \mathrm{n} .11$ (1972).

49. See text accompanying notes 50-54 infra. 
political subdivisions we know today were few. As a result, when considering eleventh amendment protection for political subdivisions, the Court focused its attention primarily on cities and counties. The rule was straightforward: immunity for the state, no immunity for cities and counties. However, as time passed and state governments grew, they undertook increasingly complex duties and created scores of less easily categorized political entities to perform them. Numerous cases arose to determine whether such entities as toll bridge authorities, ${ }^{50}$ highway commissions, ${ }^{51}$ hquor control boards, ${ }^{52}$ and state schools ${ }^{53}$ are "more like a county or city" or more like an "arm of the State." 54 These cases suggest a variety of factors that courts will consider in deciding whether a given governmental entity will enjoy eleventh amendment immunity.

(a) Incorporation and other traditional indicia of autonomy. One important consideration that the courts have relied upon simce the earliest cases is whether or not the entity in question has its own corporate indentity. ${ }^{55}$ Because incorporation generally implies the existence of a separate, self-determining entity, the fact that the state incorporated the entity arguably indicates that it intended to create a body separate from itself. Of particular importance is the corporation's power to sue and be sued in its own name. ${ }^{56}$

The older cases soinetimes referred to cities and counties simply as "corporations" and subjected them to general provisions of state corporate law. ${ }^{57}$ Another line of early cases stressed that the state could not confer its eleventh amendment immunity on a proprietary business corporation simply by allowing incorporation or by participating in the business corporation as a stockholder. In fact, the state itself would be stripped of its immunity when participating actively in the business transactions of such corporations. ${ }^{58}$ This case law could have been the

50. See, e.g., Fowler v. California Toll-Bridge Auth., 128 F.2d 549 (9th Cir. 1942).

51. See, e.g., State Highway Comm'n v. Utah Constr. Co., 278 U.S. 194 (1929).

52. See, e.g., Murray v. Wilson Distilling Co., 213 U.S. 151 (1908).

53. See, e.g., Gordenstein v. University of Del., 381 F. Supp. 718 (D. Del. 1974).

54. Mt. Healthy City School Dist. Bd. of Educ. v. Doyle, 429 U.S. 274, 280 (1977).

55. See, e.g., Moor v. County of Alameda, 411 U.S. 693, 719 (1973); Hutchison v. Lake Oswego School Dist. No. 7, 519 F.2d 961, 966 (9th Cir. 1975), cert. denied, 429 U.S. 1037 (1976).

56. Sce Moor v. County of Alameda, 411 U.S. at 719; Urbano v. Board of Managers, 415 F.2d 247, 251 (3d Cir. 1969), cert. denied, 397 U.S. 948 (1969); Roseman v. Hassler, 382 F. Supp. 1328, 1334 (W.D. Pa. 1974), affd, 520 F.2d 1364 (3d Cir. 1975); Universal Sur. Co. v. Lescher \& Mahoney, Architects \& Eng'rs, 340 F. Supp. 303, 304 (D. Ariz. 1972).

57. See, e.g., Lincoln County v. Luning, 133 U.S. 529 (1890).

58. Louisville, C. \& C.R.R. v. Letson, 43 U.S. (2 How.) 497 (1844); Briscoe v. Bank of Ky., 36 U.S. (11 Pet.) 257 (1837); Bank of Ky. v. Wister, 27 U.S. (2 Pet.) 318 (1829); Bank of United States v. Planters' Bank of Ga., 22 U.S. (9 Wheat.) 904 (1824). 
basis for the Court's finding that incorporated political subdivisions, like private corporations, cannot share in the state's immunity even though the state inaintains an active interest in the entity's functions.

The rationale behind the Court's refusal to allow the state to confer its immunity on proprietary business corporations, however, was that a corporation is a different "person" froin those who are its stockholders. ${ }^{59}$ This principle should not apply to incorporated political subdivisions since the state cannot be characterized as their stockholder. Further, a distinction can readily be inade between a state's participation in a private or semiprivate business operation and its participation in a governmental function of the kind generally pursued by incorporated political subdivisions. ${ }^{60}$

Several non-eleventli ainendment cases decided shortly before $\mathrm{Lin}$ coln County serve further to undercut the theory that incorporation of a political subdivision creates an entity so independent and distinct froin the state as logically to justify a demal of state immunity. The cases deinonstrate that incorporated political subdivisions cannot and should not be equated with private corporations.

In United States v. Railroad Co. ${ }^{61}$ the Supreine Court undertook to describe the "nature and character" of municipal corporations and their "connection with the government of the state":

[C]ities and towns . . . are allowed to assume to themselves some of the duties of the State . . . , but having neither property nor power for the purposes of personal aggrandizement, they can be considered in no other light than as auxiliaries of the government, and as the secondary deputies and trustees and servants of the people.

$\ldots$. [T] he main distinction between public and private corporations is, that over the former the legislature . . . has the exclusive and unrestrained control; and . . . as it may create, so may it modify or destroy, as public exigency requires or recommends .... . It possesses the right to alter, abolish, or destroy all such imstitutions ...62

59. Briscoe v. Bank of Ky., 36 U.S. at 323-24; see Mathis, supra note 48, at 237.

60. The courts have often recognized the distinction between governunent participation in proprietary and strictly governmental functions. Indeed, the proprietary or governmental aspects of a particular political agency are often cited as factors to be considered when deciding whether the agency is an independent subdivision or a part of the state for purposes of suit in federal court. See, e.g., Gainer v. School Bd., 135 F. Supp. 559, 569 (N.D. Ala. 1955). However, while this consideration is often recited, the inajority of cases in which state imınunity from suit has been denied have dealt with subdivisions engaged in governmental functions, rather than proprietary functions. Further, when the court determmes that it is the state itself that is directly performing a proprietary function, imınunity may be granted. Murray v. Wilson Distilling Co., 213 U.S. 151 (1909).

61. 84 U.S. (17 Wall.) 322 (1873).

62. Id. at 328-29 (footnotes ounitted). 
Again, in Mount Pleasant v. Beckwith, ${ }^{63}$ decided just one year prior to Lincoln County, the Court held that while state legislatures generally granted powers of a defined character to inunicipal corporations, this grant of powers did not prevent the legislatures from retaining unlimited control over the subdivisions' charters. ${ }^{64}$ Thus while the Court accepted the theory that private corporations are individual, autonomous entities possessing constitutional rights, it nevertheless was unwilling to equate political corporations with private corporations im this respect. ${ }^{65}$ On the contrary, the state's absolute control of the political corporation stemmed from the subdivision's role as a mere "instrumentality of the state," irrespective of the subdivision's incorporated or unincorporated status. ${ }^{66}$ The act of the state in incorporating the subdivision was not interpreted as creating an autonomous entity with rights agamst the state and the power to pursue imterests of its own. Rather, the subdivision was incorporated only because incorporation was necessary to give the subdivision the powers it needed to conduct the busmess that the state desired it to pursue on its behalf.

The fact of incorporation, then, which has so often been mentioned by the courts in distinguishing the state proper front its independent subdivisions, ${ }^{67}$ makes no practical difference in the relationship between the state and its subdivision and provides no basis for distinguishing between the two for purposes of federal court jurisdiction. Other criteria for differentiation routinely cited by the courts include the power to levy and collect taxes, ${ }^{68}$ issue bonds, ${ }^{69}$ borrow money ${ }^{70}$ enter into contracts, ${ }^{71}$ take property in the subdivision's own naine, ${ }^{72}$ and hire einployees. ${ }^{73}$ These criteria are all variations on the

63. 100 U.S. 514 (1879).

64. Id. at 529; see Meriwether v. Garrett, 102 U.S. 472 (1880).

65. It is also interesting to note that the fact of incorporation or any other implied similarity between public and private corporations has not been a significant consideration for the Supreme Court in holding that the acts of political subdivisions are the acts of the state for purposes of the fourteenth amendment. Private corporations, on the other hand, are entities apart from the state despite the fact that they are incorporated and regulated by the state.

66. Trustees of Dartmouth College v. Woodward, 17 U.S. (4 Wheat.) 518, 638 (1819).

67. Though often mentioned, the fact of mcorporation is not uniformly controlling in the determination of an entity's status. See, e.g., Gainer v. School Bd., 135 F. Supp. 559 (N.D. Ala. 1955), in which a school board, though imcorporated like a city or county, was granted state immunity against suit.

68. N.M. Paterson \& Sons v. Chicago, 176 F. Supp. 323, 324 (N.D. Ill. 1959).

69. Mt. Healthy City School Dist. Bd. of Educ. v. Doyle, 429 U.S. 274, 280 (1977).

70. N.M. Paterson \& Sons v. Chicago, 176 F. Supp. at 324.

71. Morris v. Board of Educ., 401 F. Supp. 188, 205 (D. Del. 1975).

72. George R. Whitten, Jr., Inc. v. State Univ. Constr. Fund, 493 F.2d 177, 179-80 (1st Cir. 1974).

73. N.M. Paterson \& Sons v. Chicago, 176 F. Supp. at 324. 
incorporation criterion and rest on the same underlymg proposition: if a political subdivision has the outward trappings of independence it will not receive state immunity from suit in federal court, ${ }^{74}$ even though the apparent independence of the subdivision is illusory. The independent powers test as applied by the courts may provide a handy, manageable means for drawing a line, but the existence of such powers does not provide a valid reason for inaking the differentiation in the first instance.

(b) Financial impact of a judgment on the state treasury. In recent years courts facing the question of subdivision immunity have diminished their emphasis on the subdivision's "independent" structure in favor of criteria enunciated by the Supreme Court in Ford Motor Co. v. Department of Treasury. ${ }^{75}$ In Ford Motor Co., the Court focused on the ultimate source from which funds to pay the judgment would come, holding that when the action is "in essence one for the recovery of money from the state, the state is the real, substantial party in interest and is entitled to invoke its sovereign immunity from suit . . .."76 Recently, soine lower courts have gone so far as to make the potential source of payment for a judgment the controlling factor, as in Adams $v$. Richland School District One: $:^{77}$

[W] here it appears that the money damages sought agamst the defendant would not result im any additional expenditure of public funds from the state treasury, the logical conclusion is that the protection of the eleventh amendment is unavailable notwithstanding other factors which might indicate state control over the defendant. That county funds would be used to satisfy any possible judgment is of no significance under the eleventh amendment. ${ }^{78}$

Under this theory, an ancillary or indirect effect on the state treasury is insufficient to trigger eleventh amendment protection. ${ }^{79}$ The presence of significant amounts of direct state monetary aid to the defendant also fails to create iminunity as long as the plaimtiff's success in the action will not affect the amount of state funds flowing to the defendant. $^{80}$

74. See Whitehall, The Eleventh Amendment and Sovereign Immunity: Vagaries of a Federal Fiction, 10 Tulsa L. REv. 436, 439 (1975).

75. 323 U.S. 459 (1945).

76. Id. at 464; see Edelman v. Jordan, 415 U.S. 651, 663-71 (1974).

77. 412 F. Supp. 647 (D.S.C. 1976).

78. Id. at 649; see Hutchison v. Lake Oswego School Dist. No. 7, 519 F.2d 961, 966-67 (9th Cir. 1975), cert. denied, 429 U.S. 1037 (1976); Note, A Practical View of the Eleventh AmendmentLower Court Interpretations and the Supreme Court's Reaction, 61 GEo. L.J. 1473, 1486 (1973).

79. Edelman v. Jordan, 415 U.S. at 668.

80. Hutchison v. Lake Oswego School Dist. No. 7, 519 F.2d at 966; Adams v. Richland School Dist. One, 412 F. Supp. 647, 650 (D.S.C. 1976). 
The interest in protecting state treasuries from federal interference is widely acknowledged as a major purpose of the eleventh amendment. ${ }^{81}$ Insofar as suits against political subdivisions with "independent" treasuries do indeed allow recovery without disturbing state resources, there is a reasonable basis for differentiating between the political subdivisions and their states for eleventh amendment purposes. The courts adopting this rationale, however, appear to assume that the only money the state possesses is in a central state treasury, and that any funds not in this treasury are not state funds, despite their use for state governmental purposes. This approach is unrealistic. Funds in the hands of a state-created, state-controlled government corporation must surely also be state funds. ${ }^{82}$ Numerous early cases firmly establish that the state has full control over governmental property held by its political subdivisions, and that it may direct the property's use or recall it from the subdivision at will. ${ }^{83}$ In Meriwether $v$. Garrett ${ }^{84}$ the Supreme Court recognized that the property of state-created government corporations was the property of the state: "Upon the dissolution [of the corporation], the property passes under the immediate control of the State, the agency of the corporation then ceasing." ${ }^{85}$ Furthermore, the Supreme Court has held that the revenues of a municipal corporation are, like the revenues of the state, not subject to federal taxation, smce the taxation of municipalities would hinder the right of states to "admmister their own affairs through their legislative, executive, and judicial departments, in their own manner through their own agencies ... ."86 If funds of the municipality are in fact funds of the state for tax purposes, it seems that they should be for other purposes as well.

It may be assumed that the state has granted its subdivision the power to hold funds so that the subdivision may provide its citizens with some service or benefit. Thus the state, through the political subdivision, is only doing indirectly what it might otherwise do directly. ${ }^{87}$

81. See, e.g., Hander v. San Jacinto Junior College, 519 F.2d 273 (5th Cir. 1975); Note, supra note 78 , at 1486 . See text accompanying note 94 infra.

82. See Note, supra note 39 , at $298-99$.

83. See, e.g., Hunter v. Pittsburgh, 207 U.S. 161, 178-80 (1907); Guthrie Nat'l Bank v. Guthrie, 173 U.S. 528, $529-30$ (1899); Tippecanoe County v. Lucas, 93 U.S. 108, 114 (1876); Commissioners of Laramie County v. Commissioners of Albany County, 92 U.S. 307, 313 (1875). See notes 1-9 supra and accompanying text.

84. 102 U.S. 472 (1880).

85. Id. at 513. In White v. Unatilla County, 247 F. Supp. 918,919 (D. Ore. 1965), the court noted that a county does not own funds in the county treasury in the same sense that a person or corporation owns property or money. The county funds are public property subject to legislative control.

86. United States v. Railroad Co., 84 U.S. (17 Wall.) 322, 327 (1872).

87. Railroad Co. v. County of Otoe, 83 U.S. (16 Wall.) 667 (1872); see Guthrie Nat'1 Bank v. Guthrie, 173 U.S. 528, 529-30 (1899). 
When a federal court renders a judgment against such a political corporation, the state nay be just as effectively hindered in its ability to provide the service as it would be if the judgment were rendered against the state itself. A suit in federal court against a political subdivision, then, may allow federal interference with state treasuries. ${ }^{88}$ Rather than providing a rational basis for the eleventh amendinent differentiation of states and their subdivisions, the state treasury approach argues for grantimg the subdivisions the same immunity enjoyed by the state.

(c) The laws of the state. Many courts, in deciding whether a particular political subdivision will be granted state immunity, have made a point of asserting that the state law defining the subdivision will be afforded great weight in the decisionmakmg process. ${ }^{89}$ On its face, this would appear to initigate the federalism problems inherent in differentiating the subdivisions from the state. It is apparent, lowever, that the courts are not saying that the state may, through its laws, declare its intent that a subdivision share its ininunity in federal court. Ratlier, the court will look to the inanner in which the state has structured the subdivision and then turn to federal case law to determine whether the particular structure einployed by the state will entitle the subdivision to inınıunity. ${ }^{90}$ Therefore, though state law may declare that a subdivi-

88. On the federal level, the Supreme Court has clearly indicated that the funds of a federal government corporation are the funds of the federal government. In Inland Waterways Corp. v. Young, 309 U.S. 517 (1939), the Supreme Court faced the question of whether a national bank could pledge assets to secure deposits of funds made by a government corporation in the same way that it would pledge assets to secure deposits of the United States Treasury. The Court held that

[s]o far as the powers of a national bank to pledge its assets are concerned, the form which Government takes-whether it appears as the Secretary of the Treasury, the Secretary of War, or the Inland Waterways Corporation-is wholly immaterial. The motives which lead Government to clothe its activities in corporate form are entirely unrelated to the problem .... The funds of these corporations are, for all practical purposes, Government funds; the losses, if losses there be, are the Government's losses.

Id. at 523-24. See Note, supra note 39, at 304.

89. See, e.g., Mt. Healthy City School Dist. Bd. of Educ. v. Doyle, 429 U.S. 274, 279-80 (1977); Hander v. San Jacinto Junior College, 519 F.2d 273, 279 (5th Cir. 1975); King v. Caesar Rodney School Dist., 396 F. Supp. 423, 425 (D. Del. 1975).

90. See Moor v. County of Alameda, 411 U.S. 693, 719-21 (1973); Hander v. San Jacinto Junior College, 519 F.2d at 279; Urbano v. Board of Managers, 415 F.2d 247, 250-51 (3d Cir. 1969), cert. denied, 397 U.S. 948 (1970); Wright v. Houston Independent School Dist., 393 F. Supp. 1149, $1153-54$ (S.D. Tex. 1975), vacated, 569 F.2d 1383 (5th Cir. 1978); Gordenstein v. University of Del., 381 F. Supp. 718, 720 (D. Del. 1974); Fleming v. Upper Dublin Pub. School Dist., 141 F. Supp. 813, 813 (E.D. Pa. 1956) ("While the application of the Eleventh Amendment is a question of federal law, nevertheless, ... . whether a particular state agency is entitled to immunity from federal jurisdiction . . . depend[s] upon the characteristics, capacities, powers and immunitics of such agency as they are defined by the law of (he state"); $c$. Harris v. Tooele County School Dist., 471 F.2d 218, 220 (10th Cir. 1973) (weight apparently given to state case law declaring that "school districts are instrumentalities of the state acting in its behalf"; but decision actu- 
sion is created by the state for the sole purpose of delivering an essential governmental service, if the subdivision is incorporated and capable of raising revenues it is likely to be treated as a separate entity from the state, subject to suit in federal court. ${ }^{91}$

The courts' emphasis on niechanical structure rather than the state's actual intent indicates that the consideration of state law by federal courts is, in reality, merely a mechanisin for applying federal law. As such, the test is imcapable of ameliorating the federahism probleins inherent $\mathrm{m}$ the differentiation between state and subdivision. Furtherniore, this structural eniphasis creates the state's chief dilemma. In order for the state to carry on its complex variety of governmental duties, it nuust delegate to nuanageable units. To delegate effectively, the state niust endow the units it creates with the powers necessary successfully to execute the duties delegated to then1. But if the subdivisions have these powers, they will be treated as "separate entities," and thus outside the blanket of eleventh amendinent state immunity from suit. The state's choice, then, is to choose not to delegate, which may lead to probleins of mefficient, unwieldly management, or to delegate and give up its immunity fronı suit in federal court.

\section{B. Facilitation of the Overall Purpose of the Eleventh Amendment.}

Simce cases dealing with immunity under the eleventh amendinent fail to reveal any justification for distinguishing between states and their political subdivisions, one may turn next to the purposes of the eleventh amendnient as a whole. If the purposes of the eleventh amendment are promoted by holding "the state" immune while excluding its subdivisions, the difference in treatment may be justified.

\section{Fear of War Debt Enforcement and Federal Encroachment on} State Treasuries. One of the reasons most frequently given to explain the passage of the eleventh amendment was the fear that the states would be forced, by means of suits in federal court, to pay their very considerable war debts. ${ }^{92}$ Many feared that the states would face ruin

ally based on the fact that a judgment against the school board would "ultimately reduce state funds"). See notes 55-74 supra and accompanying text.

91. See Lake Country Estates v. Tahoe Regional Planning Agency, 440 U.S. 391, 400-02 (1979); Universal Sur. Co. v. Lescher \& Mahoney, 340 F. Supp. 303, 304-05 (D. Ariz. 1972).

92. See, e.g., Baker 139; Cullison, Interpretation of the Eleventh Amendment (A Case of the White Knight's Green Whiskers), 5 Hous. L. Rev. 1, 7, 9, 17 (1967); Jaffe, Suits Against Governments and Officers: Sovereign Immunity, 77 HARv. L. REv. 1, 19-20 (1963); Mathis, supra note 48, at 212; Nowak, The Scope of Congressional Power to Create Causes of Action Against State Governments and the History of the Eleventh and Fourteenth Amendments, 75 CoLUM. L. REv. 1413, 1434 (1975); Tribe, Intergovernmental Immunities in Litigation, Taxation and Regulation: Separation of 
if forced to pay the full face value of these debts. ${ }^{93}$

If protection from payment of war debts was the sole purpose behind passage of the eleventh amendment, there may be an explanation for differentiating between the states and their pohitical subdivisions: there may have been no danger of suits to enforce war debts against cities and counties, and therefore no need to protect them. For that matter, even if subdivisions had mcurred debts similar to the states, Revolutionary War debts were no longer a concern for states or subdivisions one hundred years after passage of the eleventh amendment, when Lincoln County was decided. Excludimg subdivisions from protection might, accordingly, have been viewed as a means for narrowing the impact of an amendment no longer needed. If the amendment had indeed served its purpose, however, it should have been removed from the Constitution altogether rather than narrowed in such a way as to raise new problems under the still viable tenth amendment.

Confining the purpose of the eleventh amendment solely to protection of war debts gives the amendment an excessively narrow interpretation. It seems likely that if war debt protection were the amendment's sole purpose, it would have been worded accordingly. In fact, courts have tended to generalize the purpose of the eleventh amendment to one of protectimg state fiscal autonomy against any type of private suit for damages commenced in federal court. ${ }^{94}$ But this purpose also fails to provide a meamingful justification for differentiating between states and their subdivisions, smce the governmental property

Powers Issues in Controversies about Federalism, 89 HARv. L. Rev, 682, 683 (1976). But see C. $\mathrm{J}_{\text {ACOBS }}$ 68-70. Jacobs argues forcefully that federal judicial enforcement of war debt obligations was not a major concern in the passage of the eleventh amendment. According to Jacobs, war debts were not unmanageable at the time the eleventh amendment was passed. The Federalists, who controlled Congress at the time, believed that satisfaction of public debts was a sacred obligation. Had they seriously believed that the states would be financially irresponsible, they would never have voted for the amendment.

93. According to Cliief Justice Marshall in Cohens v. Virginia, 19 U.S. (6 Wheat.) 264, 40607 (1821):

It is a part of our history, that, at the adoption of the constitution, all the states were greatly indebted; and the apprehension that these debts might be prosecuted in the federal courts, formed a very serious objection to that instrument. Suits were instituted; and the court maintained its jurisdiction. The alarm was general; and, to quiet the apprehensions that were so extensively entertained,... . [the eleventh] amendment was proposed in congress and adopted by the state legislatures. . . . Those who were mlibited from commencing a suit against a state, or from prosecuting one which might be commenced before the adoption of the amendment, were persons who might probably be its creditors. There was not much reason to fear that foreign or sister states would be creditors to any considerable amount, and there was reason to retain the jurisdiction of the court in those cases, because it might be essential to the preservation of peace.

Id. at 406-07.

94. See Edelman v. Jordan, 415 U.S. 65I, 663 (1974); Ford Motor Co. v. Department of Treasury, 323 U.S. 459, 464 (1945); Hander v. San Jacinto Junior College, 519 F.2d 273, 277-78 (5th Cir. 1975); Note, supra note 78, at 1486. 
of the subdivision is the property of the state, and recovery from the subdivision's treasury does affect the state's fiscal autonomy. ${ }^{95}$

\section{Sovereign Immunity and Federalism. Another frequently cited} reason for passage of the eleventh amendment was the desire to imsure that the doctrine of state sovereign immumity would survive in the United States. ${ }^{96}$ The Supreme Court itself has taken this position on several occasions, as in In re Ayers, ${ }^{97}$ where the Court stated:

The very object and purpose of the 11th Amendment were to prevent the indignity of subjecting a State to the coercive process of judicial tribunals at the instance of private parties. It was thought to be neither becoming nor convenient that the several States of the Union, invested with that large residium of sovereignty which had not been delegated to the United States, should be summoned as defendants to answer the complaints of private persons . . . or that the course of their public policy and the administration of their public affairs should be subject to and controlled by the mandates of judicial tribunals without their consent, and in favor of imdividual interests. ${ }^{98}$

Scholarly commentators have argued that the eleventh amendment was meant to reverse Chisholm v. Georgia ${ }^{99}$ and reinstate the framers' original understanding that the doctrine of sovereign immu-

95. See notes 75-88 supra and accompanying text.

96. This position, like others taken regarding the purpose of the eleventh annendment, has been greatly disputed. In Cohens v. Virginia, 19 U.S. (6 Wheat.) 264 (1821), Chief Justice Marshall insisted

that [the Congress'] inotive [in passing the eleventh ainendment] was not to maintain the sovereignty of a state from the degradation supposed to attend a coinpulsory appearance before the tribunal of the nation, inay be inferred from the terms of the amendment. It does not comprehend controversies between two or more states, or between a state and a foreign state. . . . We must ascribe the amendment, then, to some other cause than the dignity of a state.

Id. at 406. See C. JACOBS, passim; Engdahl, Immunity and Accountability for Positive Governmental Wrongs, 44 U. CoLO. L. REv. 1, 9-1 1, 75 (1972); McCormack, Intergovernmental Immunity and the Eleventh Amendment, 51 N.C.L. Rev. 485, 514-I5 (1973); cf. Baker 160 (discussing problems witlı an analogy between eleventh amendinent cases and the doctrine of sovereign imununity).

97. 123 U.S. 443 (1887).

98. Id. at 505 .

99. See the concurring opinion of Justice Marshall in Employees v. Missouri Pub. Health Dep't, 4I1 U.S. 279, 291-92 (1973):

Following the decision in Chisholm v. Georgia, 2 Dall. 419 (1793), in which this Court held that federal jurisdiction encompassed a suit brought against a nonconsenting State by citizens of another State, the Eleventh Ainendment was introduced to clarify the intent of the Framers concerning the reacli of the federal judicial power . . . It had been widely understood prior to ratification of the Constitution that the provision in Art. III, $\S 2$, concerning "Controversies . . . between a State and Citizens of another State" would not provide a mechanisin for making States unwilling defendants in federal court. ... The Eleventh Ainendment served effectively to reverse the particular holding in Chisholm, and, more generally, to restore the origiual understanding . . . .

Id. at 291-92. See also Monaco v. Mississippi, 292 U.S. 313, 325 (1934); M. IrISH \& J. Prothro, The Politics of American Democracy 128 (4th ed. 1968); L. Tribe, American ConstituTIONAL LAW 130 (1978); Baker 144-45; Cullison, supra note 92, at 9; Nowak, supra note 92, at 
nity would qualify article III of the Constitution. ${ }^{100}$ It has also been suggested that the amendment was meant to enact the dissentmg opinion of Justice Iredell in Chisholm. ${ }^{101}$ Some scholars have theorized that the eleventh amendment incorporated the doctrine of sovereign immunity into the Constitution, while others beheve that it merely insured the continued existence of the doctrine in common law, free froin interference of the courts but subject to inodification by Congress. ${ }^{102} \mathrm{Re}-$ gardless of the exact approach to sovereign immunity taken by the eleventh amendment, it is questionable whether the doctrine of sovereign innunity, in any form, provides serious justification for the differentiation of the states from their pohtical subdivisions.

The doctrine of sovereign immunity was brought to the United States from England, but it does not appear that the United States' subsequent differentiation of states and their subdivisions for purposes of granting sovereign immunity was based on any parallel practice in England. Suits against counties and cities of Britain were not generally maintained at the time of and prior to passage of the eleventh ainendment. ${ }^{103}$ The extent and source of the powers and duties of these British subdivisions differed from those of their American counterparts, however, making the ineaning of this fact difficult to assess. ${ }^{104}$ Corporate franchises granted to the British subdivisions were inore nearly like those of private corporations, inaking thein less subject to legislative control than American subdivisions. ${ }^{105}$ Attempting to draw a coinparison between American and British subdivisions does not seen

1424-25; Tribe, supra note 92, at 684. Conira, C. JACOBS passim; Field, The Eleventh Amendment and Other Sovereign Immunity Doctrines: Part Onc, 126 U. PA. L. Rev. 515,531 (1978).

100. U.S. ConsT. art. 111, $\$ 2$ states: "The judicial Power shall extend to all Cases, in Law and Equity . . . between a State and Citizens of another State . . . ."

101. See Hans v. Louisiana, 134 U.S. 1, 12 (1890):

$[O] \mathrm{n}$ this question of the suability of the States by individuals, the highest authority of this country [that is, the amendment process] was in accord rather with the minority than with the majority of the court in the decision of the case of Chisholm v. Georgia; and this fact lends additional interest to the able opinion of Mr. Justice Iredell on that occasion.

Id. at 12. See also Baker 143-44; Walkup, Immunity of the State from Suit by Its Citizens-Toward a More Enlightened Concept, 36 GEO. L. Rev. 310, 322-23 (1948).

102. See Employees v. Missouri Pub. Health Dep't, 411 U.S. 279, 298 (1973) (Brennan, J., dissenting). Sce also Field, supra note 99; Field, The Eleventh Amendment and Other Sovereign Immunity Doctrines: Congressional Imposition of Suit upon the States, 126 U. PA. L. REv. 1203 (1978); Nowak, supra note 92; Tribe, supra note 92.

103. See, e.g., Russell v. Men of Devon, 100 Eng. Rep. 359 (1788).

104. It is difficult to look to the British form of sovereign immunity for answers to questions about our own, as the doctrine, when brought to the United States, was applied to a government whose philosophy and structure differed greatly from the one the doctrine was originally developed to serve. See Employees v. Missouri Pub. Health Dep't, 411 U.S. at 311 (Brennan, J., dissenting); C. JACOBS 150-55; Baker 154; McCormack, supra note 96, at 504.

105. Mount Pleasant v. Beckwith, 100 U.S. 514, 531 (1879). 
fruitful in any case, since it is not clear that the rule of county or city immunity in Britain was related to the British doctrine of sovereign immunity. ${ }^{106}$ Accordingly, British precedent does not offer a convincing explanation for the holding in Lincoln County.

In the United States, the doctrine of sovereign immunity, as it developed in state law, generally treated political subdivisions as a part of the state and entitled them to the state's immunity, at least insofar as they were acting in a governmental capacity. ${ }^{107}$ If they were to be held liable, it was because the state expressly permitted it. ${ }^{108}$ There has been no explanation why the federal law of sovereign immunity, as purportedly applied through the eleventh amendment, should differ from the state law if both the state and federal sovereign immunity laws are to serve the same general purpose. ${ }^{109}$

It is, however, by no means certam that sovereign immunity under the eleventh amendment is meant to serve the same purpose as it serves under state law. In the eleventh amendment context, sovereign immunity is an expression of the principles of federalism. ${ }^{110}$ As one scholar has terined it, while the purpose of common law sovereign immunity is to prevent courts and plamtiffs generally from interfering with the workings of government, sovereign immumity under the eleventh amendment was designed specifically to prohibit the federal government, through its courts, from interfering with the internal workings of state government. ${ }^{111}$ Indeed, Professor Jacobs has gone further to assert that

[n]either the text of the Eleventh Amendment nor the events accounting for its adoption indicate that its principal purpose was to affirm or sanction the immumity of the sovereign. The amendment can be better understood as the constitutional outcome of the first in a protracted series of confrontations between the states, on the one

106. Muskopf v. Corning Hosp. Dist., 55 Cal. 2d 211, 215, 359 P.2d 457, 459, 11 Cal. Rptr. 89, 91 (1961).

107. 2 F. Harper \& F. James, The Law of Torts $\$ \$ 29.5-7$ (1956); Baker 162.

108. The importance of sovereign immunity has declined in recent years due to its increasing unpopularity in judicial and scholarly circles. See, e.g., Nevada v. Hall, 99 S. Ct. 1182 (1979); Muskopf v. Corning Hosp. Dist., 55 Cal. 2d 211, 359 P.2d 457, 11 Cal. Rptr. 89 (1961); 1 F. HARPER \& F. JAMES, supra note 107, \& 3.18, at 277-79 (Supp. 1968); Baker 162; Cullison, supra note 92, at 6; Davis, Sovereign Immunity Must Go, 22 AD. L. Rev. 383 (1970). However, present unpopularity and the desire to restrain the doctrine does not provide a historical explanation for its limitation to the state proper under the eleventh amendment in the eighteenth and nineteenth centuries.

109. As Chief Justice Jay noted in Chisholm v. Georgia, if sovereign immunity could be claimed by a government in which the people govern, there was little reason to give it to the fifty thousand residents of Delaware and deny it to the forty thousand residents of Philadelphia, 2 U.S. (2 Dall.) 419, 472 (1793).

110. See Baker passim; Note, supra note 78, at 1483.

111. Note, supra note 78 , at $1480-81$. 
hand, and the federal judiciary, on the other, over the nature of the Federal Union and the position of the states in the constitutional order. ${ }^{112}$

Another scholar suggests that immunity from suit in federal court under the eleventh amendnent is a constitutional right guaranteed to states against individual plaintiffs nuch like immunity fronı self-incrimination is guaranteed to individuals against the state and federal governments. ${ }^{13}$

The cominon eleinent in each of these explanations of sovereign innunity under the eleventh ainendinent is the implication that the purpose of the eleventh amendinent, either at passage or through subsequent construction by the courts, was to balance the relative powers of the federal and state governments and to prohibit federal interference with the states' discretion to define and structure their own internal functions. If the purpose of the eleventh ainendment is to serve the principles of federalisin, the exclusion of state political subdivisions from its protection not only fails to further that goal but in fact frustrates it. ${ }^{114}$ The state's right freely to delegate its powers and responsibilities in the way it deenıs inost efficient is hampered by the fact that if it chooses to delegate power it inust forego the immunity it would otherwise enjoy. ${ }^{15}$ Further, judgments for damages against the treasuries of political subdivisions restrict the states' own ability to provide governmental services. ${ }^{116}$

112. C. JACOBS 161-62. Professor Warren states that a major factor inducing passage of the eleventh amendment was the fear of losing the independence of state governinents in the "increasing growth and consolidation of the powers of the Federal Government in all its branches." $1 \mathrm{C}$. Warren, The Supreme Court in United States History 92 (1922).

113. Baker 163-65. This interpretation is supported by language in Supreme Court opinions. In Edelinan v. Jordan, 415 U.S. 651 (1974), the Court, in deciding whether the state had constructively waived its eleventh annendment immunity, held: "Constructive consent is not a doctrine commonly associated with the surrender of constitutional rights, and we see no place for it here. In deciding whether a State has waived its constitutional protection under the Eleventh Annendment, we will find waiver only where stated 'by the inost express language. . . "' Id. at 673. See also National League of Cities v. Usery, 426 U.S. 833, 841 (1976).

114. Professor Baker has specifically addressed the issue of the differentiation of states from their political subdivisions under the federalism theory of the eleventh amendinent. He concludes that although subdivisions perform state governmental functions, "the courts have recognized that these units are often so removed from state government that subjecting thein to suit in federal court has few federalism repercussions." Baker 176. He observes that this is not always the case, however, and acknowledges that the policy stressed in Usery raises questions about whether state sovereignty is unhampered by denying political subdivisions the shield of immunity. Id. 175-77.

115. See note 39 supra and text accompanying notes 38-40 supra.

116. See notes $82-88$ supra and accompanying text. 


\section{The State-Subdivision Distinction in the Context of RECENT ElEVENTH AMENDMENT DEVELOPMENTS: AN OPPORTUNITY FOR CHANGE}

Eleventh amendment cases do not offer compelling reasons for providing federal court immunity to states while denying this immunity to their political subdivisions. Further, this differentiation is not necessary to accomplish the purposes for which the eleventh amendment was passed. In fact, differentiation of states and their subdivisions undercuts at least two of the chief purposes given for the amendment's passage and contnuued enforcement ${ }^{117}$ and impinges on the governmental discretion of the states in a manner inconsistent with sound principles of federalism. ${ }^{118}$ It seems appropriate, therefore, to consider abandoning the policy of differentiation im order to create a coherent eleventh amendment policy that is consistent with the rest of the Constitution.

This suggestion of change may seem disconcerting given the fact that the state-subdivision distinction has been observed for over a century, and that it has served as a basic premise underlying important decisions. Indeed, the ramifications of change at this poimt might seem even more harmful than the encroachment on federahism that the rule presently permits. On closer examination of recent eleventh amendinent developments, however, it appears that the time may be right for the change.

For the first time in many years legal scholars and the courts are subjecting the eleventh amendment and the related doctrine of sovereign immunity to close scrutimy. The Supreme Court has undertaken soine inajor adjustments in the area that have enhanced the clarity and coherence of the law and have evinced a new attitude toward the breadth of eleventli amendinent protection. The trend developing from these decisions could readily accominodate a revision in the eleventh ainendment treatment of political subdivisions.

\section{A. Recent Cases Recognizing Congressional Power to Override the States' Eleventh Amendment Immunity.}

Fitzpatrick v. Bitzer ${ }^{119}$ is the strongest evidence of this new trend in reevaluating the breadth of the eleventh amendment. In Fitzpatrick the Supreme Court held that Congress, pursuant to its power to enforce the provisions of the fourteenth amendment, could set aside state eleventh

117. See note 114 supra and text accompanying notes 114-16 supra.

118. See notes $26-27,31$ \& 34 supra and text accompanying notes 26-34 supra.

119. 427 U.S. 445 (1976). 
amendment immunity and subject states to suit for noney damages in federal court. According to the Court,

the Eleventh Amendment, and the principle of state sovereignty which it embodies ... are necessarily limited by the enforcement provisions of $\S 5$ of the Fourteenth Amendment. In that section Congress is expressly granted authority to enforce "by appropriate legislation" the substantive provisions of the Fourteenth Amendment, which themselves embody significant limitations on state authority. . . . We think that Congress may, in determining what is "appropriate legislation" for purposes of enforcing provisions of the Fourteenth Amendment, provide for private suits agamst States or state officials which are constitutionally impermissible in other contexts. ${ }^{120}$

Fitzpatrick diminishes the eleventh annendment protection of the states. The trend, however, may not end with the holding in that case. If Congress may abrogate state immunity from suit in order to enforce the provisions of the fourteenth amendment, it is conceivable that it will be found to have similar power to enforce other constitutional provisions. $^{121}$ The majority in Fitzpatrick strongly imphed that the commerce clause conveys such power. ${ }^{122}$ Following the Fitzpatrick lead, the Fifth and Seventh Circuit Courts of Appeals have since held that Congress' war powers prevail over the states' eleventh amendment immunity. ${ }^{123}$ Likewise, the Ninth Circuit has found that the eleventh amendment is subordinate to the copyright and patent clause. ${ }^{124}$ If the Supreme Court affirms such decisions, the eleventh amendment immunity from suit may be diminished to the point that Congress can remove it merely by expressing its intent to do so when it passes new

120. Id. at 456. See also Hutto v. Finney, 437 U.S. 678 (1978) (federal courts may require states to pay attorney's fees to prevailing plaintiffs in civil rights actions under the Civil Rights Attorney's Fees Awards Act of 1976, 42 U.S.C. $\$ 1988$ (1976)).

121. For a particularly interesting discussion of this proposition, see Field, supra note 102.

122. 427 U.S. at 452 . In the Fitzpatrick decision the Court relied in part upon Parden v. Terminal Ry., 377 U.S. 184 (1964). In that case it had found the State of Alabama subject to suit in federal court under the Federal Employers Liability Act (FELA), 45 U.S.C. $\$ \$ 51-60$ (1976). The Court observed that Congress had considerable power under the commerce clause to regulate common earriers, that Congress clearly intended to subject states to suit under the FELA, and that Alabama, knowing of Congress' power and intent, had continued to operate a common carrier. On these grounds, the Court concluded that Alabama had given "constructive consent" to be sued. The Fitzpatrick Court did not attempt to find constructive consent. For detailed discussions of the cases foreshadowing the Fitzpatrick decision, see Peel v. Florida Dep't of Transp., 600 F.2d 1070, 1075-77 (5th Cir. 1979); Jennings v. Illinois Office of Educ., 589 F.2d 935, 939-41 (7th Cir.), cert. denied, 99 S. Ct. 2417 (1979).

123. Peel v. Florida Dep't of Transp., 600 F.2d 1070 (5th Cir. 1979); Jennings v. Illinois Office of Educ., 589 F.2d 935 (7th Cir.), cert. denied, 99 S. Ct. 2417 (1979). See also Camacho v. Public Serv. Comm'n, 450 F. Supp. 231, 234 (D.P.R. 1978); Schaller v. Board of Educ., 449 F. Supp. 30, 32-33 (N.D. Ohio 1978).

124. Mills Music, Inc. v. Arizona, 591 F.2d 1278 (9th Cir. 1979). See also Lemelson v. Ampex Corp., 372 F. Supp. 708 (N.D. 11l. 1974). 
legislation. ${ }^{125}$

\section{B. Legal Scholars' View of Congressional Power to Override Eleventh Amendment Immunity.}

Constitutional scholars have also recently focused their attention on the eleventh ainendment, reaching important conclusions regarding the breadth of the immumity it grants to states. After considering the baffling and seemingly contradictory array of eleventh amendment cases, Lawrence Tribe concludes that

[t] he only satisfying reconciliation of the cases with a conception of the eleventh amendment as either conferring a category of rights upon the states or at least confirming the states' retention of rights agamst unconsented suit, is to distinguish rights conferred against the federal judiciary from rights conferred against Congress. ${ }^{126}$

According to Professor Tribe, nothing in the amendment's language or history suggests that it was meant to limit the power of Congress to act under its article I powers and the necessary and proper clause or the enforcement clauses of the amendments. The eleventh amendment merely limited the judiciary's power to subject the states to suit in federal court. ${ }^{127}$ Accordingly, Congress should be able to compel states to submit to federal court jurisdiction whenever it finds this necessary im the pursuit of its proper tasks. ${ }^{128}$

Similarly, John Nowak argues that while the courts have been correct in reading the eleventh amendment as a direct limitation on their own powers, the eleventh amendment poses no limitation on the power of Congress to subject states to suit, ${ }^{129}$ except that it prohibits the creation of retroactive causes of action. ${ }^{130}$ This prohibition, according to Professor Nowak, is "so basic to the eleventh ainendment that it should

125. See Quern v. Jordan, 99 S. Ct. 1139, 1147 (1979); Peel v. Florida Dep't of Transp., 600 F.2d at 1077.

126. Tribe, supra note 92, at 693.

127. Id. 693-94.

128. Id. 694. Professor Tribe points out, however, that congressional power to abrogate state sovereign immunity is not himitless. Congress cannot confer jurisdiction on article III courts beyond the boundaries drawn in that article. Further, Congress must be acting under an otherwise valid federal lawmaking power. Finally, in light of the tenth amendment, Congress may not subject states to suit if to do so would inpair state integrity or state "abihity to function effectively in a federal systein." Id. 696-97 (quoting Fry v. United States, 421 U.S. 542, 547 n.7 (1975)).

According to Tribe, the surrender of state sovereignty im areas that the Constitution expressly submits to national control is part of the constitutional plan. Tribe, supra note 92, at 694-96. Congress is the proper body to decide when the states should be inade to answer to private parties as defendants in federal courts because it is composed of representatives of the states and is therefore more "attentive to the concerns of state governments as separate sovereigns" than are the courts. Id. 695 .

129. Nowak, supra note 92 , at 1442.

130. Id. 1444. To inpose retroactive causes of action, Nowak asserts, would "seriously upset" 
be construed as applying to Congressional enactments, even though the amendment is framed only in terms of the judicial power."131

Martha Field goes a step beyond Tribe and Nowak by suggesting that sovereign immunity is a common law doctrine that is not constitutionally compelled. ${ }^{132}$ According to Professor Field, the eleventh amendment was intended only to overturn the Chisholm case, in which the Supreme Court interpreted the Constitution as abrogating sovereign immunity. ${ }^{133}$ The amendment restored the origmal constitutional neutrality on the subject, thus allowing state sovereign immunity to continue to exist in its common law form. ${ }^{134}$ Because sovereign immunity exists only in conımon law, Field concludes that Congress has the power to pass laws subjectimg the states to all types of private suits in federal court. The only checks on this power are the tenth amendment and the requirement that Congress stay within its delineated powers. ${ }^{135}$ In instances in which Congress is silent, however, the eleventh amendment prevents courts from implymg a right to sue states in federal court. $^{136}$

\section{The Diminished Constitutional Status of Sovereign Immunity.}

Professor Field's theory not only lends support to the growing trend that recognizes congressional power as a major limitation on the eleventh amendment, it also greatly reduces the constitutional status of the doctrine of sovereign immumity. ${ }^{137}$ The Supreme Court recently decided a case that diminished the importance of the doctrime on another front, lending implicit support to Field's theory.

Nevada v. Hall ${ }^{138}$ involved the question of whether a state may claim immunity frons suit in the courts of another state. Nevada, the named defendant in a personal mjury suit filed im the California courts, ${ }^{139}$ claimed that the Constitution implicitly protected it from

state fiscal policy. A state would be forced to find funds to pay for liabilities it incurred in prior fiscal years when it was unaware of its liability or the need to allocate funds to pay damages.

131. Id. Professor Nowak agrees with Professor Tribe that the courts are not the proper agents to handlc the delicate federalism issues involved in the question of federal court jurisdiction over the states. Congress is the only governmental entity that has a dual responsibility to the state and federal systems and is accountable at both levels. Id. 1441.

132. Field, supra note 99; Field, supra note 102.

133. See note 44 supra and text accompanying notes 43-44 supra.

134. Field, supra note 99 , at 538-40.

135. Field, supra note 102 , at 1227.

136. Id. 1279.

137. See note 108 supra.

138. 99 S. Ct. 1182 (1979).

139. The suit arose from an automobile accident in California between plaintiffs, California residents, and a Nevada employee driving a state car on official business. 
having to answer. Nevada argued that at the time the Constitution was ratified there was a common understanding that no sovereign was amenable to suit in any court without its consent, an understanding repeatedly reflected in Supreme Court opinions. ${ }^{140}$

The Court rejected the argument that the Constitution implicitly denies one state jurisdiction over another. "In the past, this Court has presumed that the States intended to adopt policies of broad comity towards one another. But this presumption reflected an understanding of state policy, rather than a constitutional command."141 State immunity from suits in the courts of other states, the majority held, is only "a matter of connity" that the states may reject if they choose. ${ }^{142}$ For the federal courts to hold "by inference from the structure of our Constitution and nothing else"143 that California was not free to enforce its own legal policies against another sovereign would constitute a severe intrusion on California's sovereignty contrary to the dictates of the tenth amendment. ${ }^{144}$

The Hall decision does not directly relate to the question of sovereign immunity under the eleventh amendment. Nevertheless, the Court's rejection of Nevada's argument that the doctrine is implicitly guaranteed by the Constitution may indicate that the Court would also accept Professor Field's contention that the eleventh amendment does

140. $99 \mathrm{~S}$. Ct. at 1185. See Justice Rehnquist's dissent for a detailed analysis of these cases. Id. at 1194-99.

Nevada also argued that even if the California courts did have jurisdiction, the full faith and credit clause, U.S. CoNST. art. IV, § 1, required California to observe a Nevada statute limiting the damages that could be awarded against the state. The Court rejected this contention. "Full faith and credit . . . does not here enable one state to legislate for the other or to project its laws across state lines so as to preclude the other from prescribing for itself the legal consequeuce of acts within it." 99 S. Ct. at 1190 (quoting Pacific Ins. Co. v. Industrial Accident Comm'n, 306 U.S. 493, 504-05 (1939)).

141. $99 \mathrm{~S}$. Ct. at 1191.

142. $I d$.

143. Id.

144. Id. The Court noted that California's exercise of jurisdiction posed "no substantial threat to our constitutional system of cooperative federalism." A simple personal imjury case could "hardly interfere with Nevada's capacity to fulfill its own sovereign responsibilities." Id. at 1190 n.24. The case offered no occasion to consider whether other state actions "might require a different analysis or a different result." $I d$.

Dismissing this reservation, Justice Blackmun, in his dissent, termed the majority's holding as a "basic and undeniable ruling ... that what we have always thought of as a sovereign State is now to be treated in the courts of a sister state . . . just as any other litigant." Id. at 1192 (Blacknuun, J., dissenting).

Justice Rehnquist also wrote a stroug dissent: "[T]he Court's decision today works a fundamental readjustınent of interstate relationships which is impossible to reconcile not only with an 'assumption' this and other courts lave entertained for almost 200 years, but also with express loldings of this Court and the logic of the constitutional plan itself." Id. at 1194 (Rehnquist, J., dissenting). 
not make sovereign immunity constitutionally required. In any event, the case indicates that the Supreme Court may be reconsidering the importance of the doctrine of sovereign immunity. As the Court becomes less synupathetic to state immunity to suit, it may become even more sympathetic to the claim that Congress may subject states to suit in federal court.

\section{Implications of the Eleventh Amendment Transition for the Differentiation of States and Their Subdivisions.}

It is clear that eleventh amendment doctrine is undergoing rapid and far-reaching change. The scope of eleventh amendment immumity has been and may continue to be diminished through congressional action, while the decline of the constitutional status of sovereign immunity may ultimately shrink eleventh amendment protection still further.

The implications of these innovations in eleventh amendment jurisprudence are important to a proposal to dispense with the differentiation of states and their political subdivisions. Since the law is the throes of change, a further reahgnment could be accommodated with greater ease than it might were the law well settled. Further, as the number of imstances im which the eleventh amendment will shelter states from suit in federal courts decreases, the impact of allowing political subdivisons to share in that reduced immumity lessens.

Of course, one might observe that if the states themselves are subjected to suit in federal court more often, the undesirable effects of distinguishmg states from subdivisions will be diminished. For example, if states find themselves subject to frequent suits in federal court due to a narrowing of eleventh amendment protection, the fact that a delegation of power waives their narrow immunity may carry so little weight as never to deter states from freely delegating duties to subdivisions. Accordingly, the nitrusion on the principles of federalism will not be as great as it is now. However shght the impact that differentiation ultimately has on federalism, though, there is still cause to discontimue the practice. First, since there is no utility in the differentiation to counterbalance the harm to federalism, there is no reason to tolerate the encroachment, however small. Further, abandoning the deviant definition of "state" under the eleventh amendment and adopting the definition as it is used in other parts of the Constitution will bring greater consistency and coherence to the interpretation of the document as a whole. Finally, by treating states and their subdivisions in the same way, federal courts would be freed from the difficult and fruitless task of distinguishing between those subdivisions that are "arms of the 
state" and those that are not. ${ }^{145}$

\section{CONCLUSION}

The courts have treated political subdivisions of the states as independent entities for eleventh amendment purposes despite the fact that this practice furthers no eleventh amendment goals and is contrary to sound principles of federahism. Current trends in eleventh amendinent and sovereign immumity jurisprudence offer a unique opportunity for the courts to discontmue this practice and to grant pohtical subdivisions immunity from suit in federal court that is equal in scope to the immunity enjoyed by their parent states. This reassessinent would yield consistent treatment of states and subdivisions in all constitutional inatters, add coherence to the Court's interpretation of the Constitution as a whole, and eliminate an unjustified restriction on the discretion of the states.

Margreth Barrett

145. See text accompanying notes 50-91 supra. 
HeinOnline -- 1979 Duke L.J. 10701979 